Kente: Cape Coast Journal of Literature and the Arts

Online ISSN: 2579-0285

https://doi.org/10.47963/jla.v2i1.238

Speak Like You Were Dead: Episteme of the Ghosted in Aravind Adiga's The White Tiger

Sharmila Mukherjee 


\section{SPEAK LIKE YOU WERE DEAD: EPISTEME OF THE GHOSTED IN ARAVIND ADIGA'S THE WHITE TIGER}

Sharmila Mukherjee

Bronx Community College at the

City University of New York, USA

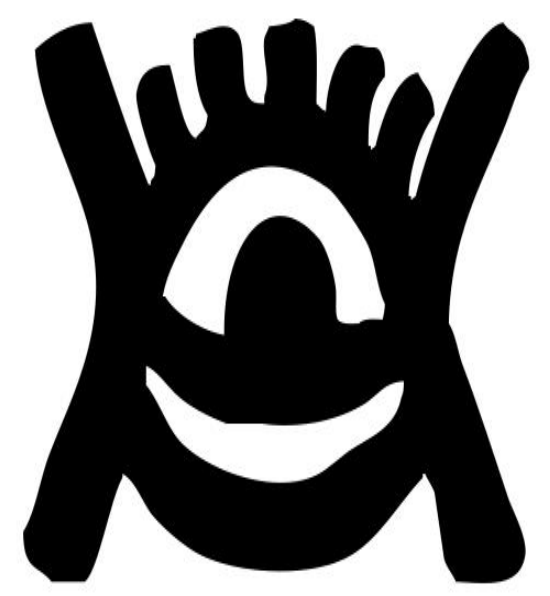

\begin{abstract}
Aravind Adiga's 2008 Man Booker Prize-winning novel, The White Tiger has been hailed as a paradigmatic narrative of postcolonial wealthformation in the $21^{\text {st }}$ century, and as a novel that speaks to the "shining" India of globalization in its transformative moment of an emergent centrality on the global stage. I argue that The White Tiger, by using counter-intuitive epistemes, is also a transnational novel whose primary motive is to offer a trenchant critique of global neoliberalism, and its underlying epistemes of violence and inequality. Through the voice of its protagonist Balram Halwai, the novel, I claim, projects the $21^{\text {st }}$ century postcolonial nation of India as Capital's colony - a thriving and free "market", if you willwhose well-being, in turn, is predicated on the phagocytizing of the human capital of the other India that is hidden from the gazes of those who admiringly gawk at "shining" India of Capital.
\end{abstract}

KEYWORDS

Capital, epistemic violence, India postcolonial anglophone novel of protest, neoliberalism

CONTACT Sharmila Mukherjee: email: sm396@nyu.edu 
KENTE, 2021

Vol.,2 No.1

In 2007 The Times Group, India's largest English-language media conglomerate, aired an infomercial entitled "India Poised." Produced on the occasion of the nation's $60^{\text {th }}$ year of independence (from British colonial rule), "India Poised" positions itself as an anthem that celebrates $21^{\text {st }}$ century India's newly-minted status as an emergent economic superpower. Contemporary India, the anthem posits, is no longer a foreign aid-dependent, developing nation, strapped meekly to an atavistic socialist order, but a free-market "hound", hungry for capital."1 The paean, however, is not dedicated to a vision of a unified India, woven into a single fabric out of its diverse lived socio-economic experiences. It's a validation of only one India, popularized in the national imaginary as economically ascendant. But in order to affirm - in the much adulated Bollywood megastar Amitabh Bacchan's baritone that's guaranteed to elicit an affective response from the audience - the India of promise, progress and modernity, another India, darkened by persistence of structural poverty, has to be disavowed: "There are two Indias in this country. One India is straining at the leash, eager to spring forth and live up to all the adjectives that the world has been recently showering on us. The other India is the leash." (TOI, 2007). In other words, the anthem prioritizes the India that's "poised" to take flight as a neoliberal utopia, by seceding, if necessary, from the "other" "leash" like India that looks down "from the edge of the precipice [...] into the ravine" of what could be deemed as systemic neglect and exploitation. In the neoliberal paradigm the India of the "ravine" is however not impoverished by the state's structural and real violence but by virtue of characterological drawbacks. In a neoliberal model of development poverty (in India) is often a byproduct of sloth, lack of individual responsibility and an irrational loyalty to the backward-looking politics of agrarian Marxism. ${ }^{2}$

Borrowing from Sebastian Garbe, ${ }^{3}$ I'd argue that by predicating the formation of a new India of rising GDP, on the literal and figurative erasure of the India of precarity, or the India that is not

\footnotetext{
1 "India Poised" goes thus: There are two Indias in this country. One India is straining at the leash, eager to spring forth and live up to all the adjectives that the world has been recently showering upon us. /The other India is the leash. /One India says "Give me a chance, and I'll prove myself." /The other India says "Prove yourself first, and maybe then, you'll have a chance."/One India lives in the optimism of our hearts. /The other India lurks in the skepticism of our minds. /One India wants. /The other India hopes. /One India leads. /The other India follows. /These conversions are on the rise. With each passing day, more and more people from the other India are coming over to this side. And quietly, while the world is not looking, a pulsating, dynamic India is emerging. /An India whose faith in success is far greater than its fear of failure./An India that no longer boycotts foreign-made goods, but buys out the companies that makes them instead./History, they say, is a bad motorist. It rarely ever signals its intentions when it's taking a turn. /This is that rarely ever moment. History is turning a page. /For over half a century, our nation has sprung, stumbled, run, fallen, rolled over, got up and dusted ourselves, and cantered, sometimes lurched on. /But now, in our sixtieth year as a free nation, the ride has brought us to the edge of time's great precipice./And one India, a tiny little voice at the back of the head, is looking down at the bottom of the ravine, and hesitating. The other India is looking up at the sky and saying, "It's time to fly."

2 Ramachandra Guha, "Adivasis, Naxalites and Indian Democracy", Economic and Political Weekly, Volume 42, No. 32 (August, 2007)

${ }^{3}$ Quoted in James Coleman, "Social Capital in the Creation of Human Capital", The American Journal of Sociology, Vol 94, 1988
} 
necessarily the beneficiary of economic globalization, "India Poised", stages an act of epistemic violence on the latter India. Building on Gayatri Spivak's seminal offering of the project of knowledge production of the colonial Other, being simultaneously "an asymmetrical obliteration of the trace of the Other in its precarious subject-ivity,"4 Garbe defines epistemic violence as a "forced delegitimation, sanctioning and repression [...] of certain possibilities of knowing, that goes hand in hand with an attempted enforcement of other possibilities of knowing." 5 As a paradigmatic narrative of $21^{\text {st }}$ century India's moment of extraordinary blooming in Capital's history, "India Poised" with its visual framing of the emergent India of dynamicism (though not necessarily of democracy) against the backdrop of the Bandra Worli Sealink, a massive infrastructural undertaking for roughly $\$ 318$ million, preempts access, or even a desire for access, to the life-worlds of those on whose backs, as it were, the dominant narrative of the nation is propagated. But can those silenced by epistemes of capitalist appropriation and expropriation in neoliberal India speak back or dismantle frameworks of violent knowledge production under conditions of erasure? According to Arundhati Roy, writer, political activist and chronicler of the lives and deaths of the wretched of the Indian earth in the postcolony, the subaltern of contemporary India have no choice but to enunciate their positions of contestation, not because they are threatened by mere erasure; if they don't reinscribe themselves into the body of the dominant national narrative on terms of their own precarity and scramble the grammar of neoliberal violence, then they face death itself_- both literal and epistemic.

Standing in front of, or rather confronting with an oppositional gaze, ${ }^{6}$ Antilia, the Mumbai dwelling of Mukesh Ambani, a businessman, listed by 2021 Forbes as the richest person in Asia, ranked 10 amongst global billionaires with a net worth of $\$ 84.5$ billion, Roy asks a morally critical question. On the demolition of whose homes and bodies, does this imposing private residence stand? Or, which episteme normalizes Antilia's existence despite its $\$ 1$ billion contiguity to Dharavi, one of Asia's largest slums? Predicating her anger on a Marxian dictum that an excess of uncontested capitalism will one day conjure up the "ghosts" of those decimated by its structural violence from the nether world to which said violence has consigned them, Roy further asks, on what spirits of the nether world is the Ambani house premised? Her response: "The poltergeists of dead rivers, bald mountains and denuded forests; the ghosts of 250,000 debt-ridden farmers who have killed themselves and of the 800 million who have been impoverished and dispossessed to make way for us. And who survives on less than 20 rupees a day." The Ambani dwelling, like the Sealink of "India Poised," could be said to be grounded on the physical and symbolical demise of those on whom it has battened. In neoliberal India of capitalist appropriation and violence, the relationship thus discerned between the superstructures and the bases can no longer be contained

\footnotetext{
${ }^{4}$ Spivak, Gayatri, "Can the Subaltern Speak? Reflections on the History of an Idea.” 2010. Print.

5 Quoted in James Coleman, "Social Capital in the Creation of Human Capital", The American Journal of Sociology, Vol 94, 1988

${ }^{6}$ Arundhati Roy, My Seditious Heart: Collected Non-Fiction, Haymarket Books, New York, New York, June 2019
} 
within the traditional Marxist analytic of a class struggle between dominant/empowered and subordinate/disempowered; the relationship leeches into that of the living and the dead.

In what follows, I explore the possibility of the emergence of a "poltergeistic" episteme in Anglophone Indian fiction that exposes contemporary social, political and economic inequities, and ask how a counter-narrative of the "dead" might tell us not only about the violence of the neoliberal polity in the Global South, but also about vernaculars of resistance to reclaim liberty, life and subjectivity from necropolitical processes of the everyday life of the poor and the degraded. I do so by using Aravind Adiga's 2008 Booker Prize-winning dark dramatic monologue The White Tiger, as a representative instance of the use of a spectral discourse to menace/disrupt the (narrative) formation of a unitary "India", "poised" to take on the mantle of a global sovereignty.

But before turning to Aravind Adiga's The White Tiger whose governing epistemology, I claim, is that of the "ghost", a brief detour to the episteme itself is in order. I'd posit it as primarily a locutionary act of outrage from those in the subjectivity-transcending positions of "ghosts" or from those who have been literally ghosted by the statist forms of power as not deserving of even a minimal social value. Or, to frame it in terms of Judith Butler's argument, the possible sites of production of spectral episteme are those "grievable" bodies, who remain un-mourned upon death because even while living, these bodies were counted among the dead or not counted as "life". Butler classifies bodies in nations and transnational bodies in constant states of uprootedness, as "grievable" and "ungrievable" in the context of perpetual war. ${ }^{7}$ These are political bodies, deemed grievable or ungrievable by the political sovereignty that decides who lives and who dies. ${ }^{8}$ In the context of postcolonial India, the ungrievable bodies are not necessarily casualties of war, but more likely of a visceral denudation of humanity, where the body is good only as far as it's resourceful or capable of producing visceral labor to the total exclusion of the body's well-being or place in the human spectrum. In The White Tiger, for example, the water buffalo, which the rural poor in the India of "darkness" keep as source of family income, is as "fat" as India's rich, signifying its place in a symbolic economy where corpulence is a metonymy of social power and wealth. Balram Halwai, the novel's protagonist, himself an embodiment of ungrievability, and valuable only as a body in labor, observes the water buffalo to be the "most important member" of the family. He meditates further on the buffalo's condition as the

Fattest thing in our family; this was true in every house in the village. All day long the women fed her, and fed her fresh grass. Feeding her was the main thing in their lives. All their hopes were concentrated in her fatness, sir. If she gave enough milk, the women could sell some of it, and there might be a little more

\footnotetext{
${ }^{7}$ Holly Brown, "Judith Butler in Belgium: Reflections on Public Grief and Precarity in the Wake of the Paris Attacks", DiGeSt, Journal of Diversity and Gender Studies, Vol. 3, No. 1, 2016, (pgs. 7-16) ${ }^{8}$ lbid
} 
KENTE, 2021

Vol.,2 No.1

money at the end of the day. She was a fat, glossy-skinned creature, with a vein the size of a boy's penis sticking out over her hairy snout, and long thick pearly spittle suspended from the edge of her mouth; she sat all day in her own stupendous crap. She was the dictator of our house! (105)

The granting of subject status, howsoever compromised the status is, on the buffalo (like their human keepers they too are lambs to the slaughter for capitalist consumption) is in contrast with the ghosting of the human subject, described as bodies in abjection, whittled down to "human spiders." Halwai introduces the spectre of the "human spiders" to his silent interlocutor, the Chinese Premier Wen Jiabao, thus:

Go to the tea shop anywhere along the Ganga, sir, and look at the men working in that tea shop - men, I say, but better to call them human spiders that go crawling in between and under the tables with rags in their hands, crushed humans in crushed uniforms, sluggish, unshaven, in their thirties or forties or fifties but still "boys." But that is your fate if you do your job well - with honesty, dedication, and sincerity, the way Gandhi would have done it, no doubt. (125)

The tea shop men are already always constituted as ghosts living outside the pale of what's normatively human. The governing logic of a poltergeistic episteme, "cooked" in the "skulls" of ungrievable/ghosted objects like Balram Halwai and the tea shop men, is to humanize and transform into grievable subjects because "grievability is a presupposition" for life. ${ }^{9}$ However, spectrality in a postcolony can offer advantages. The invisible cannot be countered for staking out a position of unadorned "truth". The truth spoken in its political dimension, as Judith Butler remarks, risks retaliation or "assassination" from authority that's threatened by said truth. The truth therefore is often veiled or shrouded in ambiguity out of fear of repercussion. ${ }^{10}$ No such disabling conditions are likely to mar the discursive field that a poltergeistic episteme constitutes. The position of spectrality is paradoxically a liberating position as well. Halwai is not only daring or brazen, but fundamentally free to tell the "truth" of postcolonial India as not one but two Indias: a necropolitical state of darkness eclipsed from world view by the resplendence of the entrepreneurial India drooled over as poster child for neoliberalism's success. In a delirious nonconformity with standard knowledge-constituting epistemes, Halwai provincializes the India of capital's construing ${ }^{11}$ by using an array of heterogenous idioms, ranging from Bollywood

\footnotetext{
${ }^{9}$ Ibid

10 Ibid

${ }^{11}$ Dipesh Chakrabarty, Provincializing Europe: Postcolonial Thought and Historical Difference critiques the mythical figure of Europe that is often taken to be the original site of modernity. Might modern India with its integration into the global market be construed as progressive, modern and liberal be a construct of the West, capital's derivative asset?
} 
histrionics, scatology, profanity, to sacrilege (both "Ganges" and "Gandhi" touted as icons of India's essential purity, are guffawed at as byproducts of fake historiography), among other technologies of subversion. His reckless abandon comes from his positionality. He is both in India and out of it; he is both in the history of capital and out of it, sitting as he does in a liminal geography of his sparse "office" atop a corporate high rise in the Indian city of Bengaluru, the globe's technology "driver". The sole marker of his being-in-the world is a chandelier, under whose lighting Halwai composes epistles on his "silver Mackintosh" laptop, both celebrating and exposing India, but finally repudiating it as a project of inauthentic, hence incomplete, modernity, being structurally similar to the Antebellum American South of radical inequality, servitude and confinement. Halwai's troping of $21^{\text {st }}$ century India as an ecosystem of slavery, has shock value, as though following in the footsteps of novelist Jeffrey Eugenides' advice given to aspiring writers to "write as if you were dead", ${ }^{12}$ Halwai is free to produce knowledge of a hidden India in forbidden terms because he is speaking from outside the event horizon of history itself. Unlike Eugenides' acolytes, he doesn't have to conjure up a subject-position outside of corporeality; he is, in the analytic registers of history an incorporeal subject. As a "ghost" of the $21^{\text {st }}$ century Indian imperium, speaks to re-present history, not necessarily to change its course. However, despite its contra-Marxian timber, the implications of the episteme of the ghosted, are radical. The creation of a discursive field from beyond the events horizon of history is a necessity because history has been an instrument of "buggery" - to borrow from Halwai's sexually inflected lexicon — for the poltergeists of India. They have been "buggered" twice, once by the epistemic violence of colonial historiography and again by the neocolonial state apparatus of postcolonial India.

Critics of The White Tiger have typically gravitated away from epistemic into thematic concerns of the novel. The novel's central event, or the event that has been centralized into a binding episode - Halwai's bludgeoning of his master to death - has driven a slew of interests in the theme of violence. Indeed the murder can be read as the "flood" that changes the course of the narrator's life, the occurrences prior being antediluvian and those tumbling after as post in the novel's plot structure. ${ }^{13}$ In an essay entitled "Poor-Rich Divide in Aravind Adiga's The White Tiger", A.J. Sebastian considers the event of the homicide as the transformative event that separates the "primordial" Balram — an yet-unindividuated member of a faceless mass of the exploited and the abject - from the Balram who acquires personhood and a "conscious ideology of resentment" that signals to the world the violent consequences of unresolved social inequality. ${ }^{14}$ Violence has been noted as a necessary pathway to breaking away from an enchainment to the "great Indian rooster

\footnotetext{
12 https://www.newyorker.com/books/page-turner/posthumous

13 Prakash Chandra Patel, "Aravind Adiga's The White Tiger: A Critique of Class War and Voice of the Voiceless", Language in India, Vol 18:4, April 2018

${ }^{14}$ A.J. Sebastian, "Poor-Rich Divide in Aravind Adiga's The White Tiger", Journal of Alternative Perspectives in the Social Sciences (2009) Vol 1, no. 2, pgs. 229-245
} 
coop", ${ }^{15}$ a defining motif of servitude in the novel. Arguing in a Fanonian vein, Liani Lochner identifies subaltern violence enacted by Halwai as a rational response to the originary violence of the state in both postcolonial and neoliberal India, thus reading the choices that Balram makes through the prism of an inchoate class warfare. ${ }^{16}$ Citing the historical absence of traditional class warfare in postcolonial India, the critic Megha Anwar makes a case for the exceptionalism of the violence of "White Tigritude" in order to critique the futility of solving the problem of historical inequity in India with eruptions of individualized acts of brutality and revenge. She claims that White Tigritude is a tragicomic flash in the pan, or one of a kind of violent intervention that gains the hero plaudits and pivots the novel toward a socially dissatisfying bildungsroman of blood and redemption. ${ }^{17}$ Violence is inarguably the governing theme in The White Tiger; however I would contend that the novel pivots more toward Halwai's and by default the new Indian imperium's ghosted subjects' thirst for freedom, particularly narrative freedom to tell the story of "India" with violent impunity in their own grammar over the grammar of neoliberal nationalism.

The novel is structured as a dramatic monologue in which the subaltern - a servant cum driver of the rich-castigates, with comic garrulity (and critical acumen) the sanctioned history of India to be a lie, at best a hegemonic construct of the corrupt elite to advance their own interests in the world and at worst, a fictional thicket to hide the frightful truth of India as nation of pervasive inequality and class (and caste) segregation. The mediatedness of Adiga's fictional rendering of the subaltern notwithstanding - the protagonist thinks and speaks in syntactically perfect English - it can be argued that White Tiger problematizes mainstream histories of postcolonial India. ${ }^{18}$ An informal episteme, of the kind that circulates in the medium of rumor, informs the monologue of Balram Halwai, the novel's loquacious subaltern narrator, as he decenters "India", uninterruptedly for nine days and nine nights. Halwai's colloquial accounting of India produces a nation that's the binary opposite of a formal version: "One fact about India is that you can take almost anything you hear about the country from the prime minister and turn it upside down and then you will have the truth about that thing" (12). The official discourse claims that India is a "free" country, having attained its political independence from Britain in 1947; yet, writes Halwai, “...this land, India, has never been free. First the Muslims, then the British bossed us around. In 1947 the British left, but only a moron would think that we became free then" (18). In contending

\footnotetext{
${ }^{15}$ Sara Schotland, "Breaking Out of the Rooster Coop: Violent Crime in Aravind Adiga's The White Tiger and Richard Wright's Native Son",

${ }^{16}$ Liani Lochner, "The Politics of Precarity: Contesting Neoliberalism's Subjects in Aravind Adiga's The White Tiger," English Academy of Review: A Journal of English Studies, Vol 31, Issue 2, 2014.

${ }^{17}$ Megha Anwer, "Tigers of an-Other Jungle: Adiga's Tryst with Subaltern Politics", Journal of Postcolonial Writing, March 2014.

18 The majority of references to "history" are drawn from historian Dipesh Chakrabarty's phenomenal work on the narratives of European and non-Western history in colonial modernism: Provincializing Europe. In his book Chakrabarty sees two kinds of histories emergent in colonial modernity, History 1 or the history of capital that subsumes all other formations or History 2's. History 2 are the life worlds of lived experiences that often collide with and even contest the smooth formation in time of History 1.
} 
that India has never been truly a free nation, Halwai not only discomposes historiography per sei.e. dismantles centrality of an essentially Eurocentric rendering of "World history,"19 — but also devalues Indian nationalistic history, for to assert that Indian freedom has been a myth rather than a fact of history, is to tread into anti-national territories. However, theoretically speaking, Halwai could also be said to be chiming in with the view of subaltern studies; subalternists typically argue that the postcolonial state carries with it complex legacies of colonial structures of dominance, such that the relationship between elite-run Indian state and the "peasantry" or subaltern remains one between the ruler and the ruled, the free and the subordinated. Again, Halwaian allegations of perpetual Indian servitude could also be a sly reference to what historian Partha Chatterjee has labeled as epistemic subjection in the postcolonial state. In Nationalist Thought and the Colonial World (1992), Chatterjee suggests that nationalist thought operates "within a framework of knowledge whose representational structure corresponds to the very structure of power it seeks to repudiate. ${ }^{20}$ In other words, nationalism may succeed in liberating the nation from colonialism but not from the knowledge system of the post-Enlightenment West, which may continue to dominate maybe even more powerfully. Through Halwai, novelist Adiga could be said to be articulating absence of true freedom in contemporary India at heterogenous levels of possibilities.

The novel, however, begins on a patriotic note with a hailing of India, represented synecdochically by the "brown" race. Halwai, having risen from the lowly status of a driver to that of a successful entrepreneur, proclaims in a fit of overweening confidence, "The future of the world lies with the yellow man and the brown man (now that our erstwhile master, the white-skinned man, has wasted himself through buggery, cell phone usage, and drug abuse)." (4) Halwai's vision of an Asiatic future culminates in a folksy augury of a consummate transfer of power from the global North to the South. He is holed up in his office in the heart of the city of Bengaluru, the globe's "technology driver," composing "epistles" to the Chinese Premier, who is scheduled to visit India to tour the $21^{\text {st }}$ century sites of its remarkable achievements. In his $7^{\text {th }}$ epistle Balram writes, "White men will be finished within my lifetime... My humble prediction: in 20 years' time, it will be just us yellow men and brown men at the top of the pyramid, and we'll rule the whole world." (262) The sweeping rudimentarity of Balram's geopolitics notwithstanding, the "prediction" of the substitution of "white" sovereignty by a brown and yellow one, is in tune with contemporary neoliberal foresayings about the world's "Chindian" future. ${ }^{21}$

\footnotetext{
${ }^{19}$ A reference to Hegel's and Marx's notion of history as progress. Hegel regarded history as an intelligible process moving toward a specific condition - the realization of human freedom.

${ }^{20}$ Chatterjee, Partha. Nationalist Thought and the Colonial World: A Derivative Discourse. Minneapolis: University of Minnesota Press, 1986. Print.

${ }^{21}$ A significant global development in the first decade of the $21^{\text {st }}$ Century has been the rise of several nations hitherto not considered key players in the international scene. The following up and coming nations have recently been grouped respectively as BRIC and BASIC: Brazil, Russia, India, and China (BRIC); and Brazil, South Africa, India, and China (BASIC) (Wilson \& Purushothaman, 2003). Noticeably, the two nations featured in both these groupings are China and India. China's and India's meteoric rise to the global arena, and the sheer magnitude of their populations, has led some scholars to assert that there is an 'irresistible' shift of global power toward Asia, dubbing this as the 'Asian
} 
But the brown India that's extolled is the elite India of "light," the India that officialdom will be showcasing to the Chinese dignitary, and by default, to the world, as the India of totality. What will be concealed from the world's view is the India of "darkness." Halwai, himself a citizen of dark India who has made it into the light through controversial means, wants his audience to see the nation as problematically riven in two Manichean halves: "I am talking of a place in India...at least a third of the country... Those who live in this place call it the darkness. Please understand, Your Excellency that India is two places in one (12). The India of "light" dominates while that of "darkness" cowers; the former is predatory, while the latter is prey. The (en)lightened India, epitomized by the thriving cities of Bengaluru, New Delhi and Mumbai, among others, enjoys the fruits of globalization, whereas, its stygian bottom half, represented in the novel by the benighted state of Bihar, is inked in despair, destitution and illiteracy. What inheres - shockingly so - in the $21^{\text {st }}$ century landscape of India rendered thus, are deeply colonial structures, not only of economic disparity, but of life and death. Assuming, as theorist Achilles Mbembe does, in the context of "necropolitics" practiced in the modern postcolony, that the ultimate expression of sovereignty resides to a large degree, in the power and capacity to dictate who may live and who may die, the novel, "The White Tiger" implies that in the $21^{\text {st }}$ century Indian postcolony, statist sovereignty assigns life to the rich and death to the poor. ${ }^{22}$ In other words, the novel conceives the homeland as a necropolis, disrupting, in the process, the coherence of the official image of India as a timeless composite of transcendence and Gandhian non-violence. Disruption of orthodox conceptions of the nation is the pith and marrow of Adiga's novel. In a formative moment of his life, Balram intuits India's necropolitical ethos. While in school, a visiting official marks him out of the crowd (because he has been able to rattle off accurately the teachings of Mahatma Gandhi) and says: "You, young man, are an intelligent, honest, vivacious fellow in this crowd of thugs and idiots. In any jungle, what is the rarest of animals - the creature that comes along only once in a generation?" He asks Balram, who is yet unchristened, his name. In response Balram says "[t]he white tiger", and the official retorts "That's what you are, in this jungle" (35). In a nutshell, the White Tiger's life-trajectory, like those of the life-trajectories of his ilk, is to survive in a post-independence India that's a lawless menagerie. In an extraordinary revisionism of colonial history, Balram notes that bestiality is immanent in the Indian DNA; colonialism, claims Halwai, humanized the nation temporarily, only for postcolonial India to lapse into recidivism: "On the fifteenth of August, 1947 - the day the British left - the cages had been let open; and the animals had attacked and ripped each other apart and jungle law replaced zoo law" (63-4). The infamous riots in which about 2 million people died and millions more were displaced, are stripped of historical causality and crystallized into an event of sheer internecine violence; to Balram, colonial India, "in its days of greatness, when it was the richest nation on earth was like a zoo. Everyone in his place, everyone

Century' (Mahbubani, 2008, p. 43). And some scholars have gone so far as to coin the portmanteau 'Chindia' to signify the ascendency of these two Asian giants (Ramesh, 2005; Sheth, 2008).

${ }^{22}$ Mbembe, Achille. On the Postcolony. Berkeley: University of California Press, 2001. Print 
happy" (63). ${ }^{23}$ In the aftermath of independence, according to Balram, ex-colonial subjects had to adjust to "the law of the jungle"; when the British left, the managed and disciplined zoo became a wilderness of destitution and inequality, a fraudulent jungle where democracy is a sham, and where elections are customarily bought and sold and villagers from the Darkness prattle ineffectually "like eunuchs discussing the Kama Sutra" (98). "[T]hanks to all those politicians in Delhi" (64), independence has resulted in conflict between Balram's desires to escape casteism and classism and the constraints imposed by culturally-embedded corruption. The cunning and resourceful Halwai posits that in India's current state of affairs, the uneducated ("half-baked") and underprivileged individual can surmount the restrictions imposed by caste and class through the technology of crime and politics; for, according to Halwai, in present day India there is available only two forms of existences - to either "eat - or get eaten up" (64).

A necropoliticized subject is also a radicalized one. Halwai argues that he has no vision of an ideal India; he only sees it for what it is or for what it has been to him - a machinery of systemic and corporeal violence. Occupying a subterranean rung (lower than the lowest) in the ladder of both class (abjectly poor) and caste filiation and experiencing no ontic sense of belonging to any particular structure of Indian feeling, Halwai invents his own universals and rejects the existing one's of history as "fucking" joke(s). Halwai's act of provincializing India of the elite imperium, is more imprecative than cogitative. Presumed to be a bona fide servant, hailing from an India of "darkness" that has never, except in mythical lore of prehistory perhaps, been touched by anything propitious, and where even that which is conventionally deemed to be propitious, or sacred-like the river Ganges, the giver of all life authentically Indian in popular parables - manifests itself "blackly", and excrementally, being "full of faeces, straw, soggy parts of human bodies, buffalo carrion, and seven different kinds of industrial acids" (15), Halwai has nothing to be grateful for and everything to be jeeringly refusing of. In his verbal lashings of capital and of official narratives of the new Indian ingress into capitalist modernity, Halwai is, it could be contended, more unambivalently Talebanic than Calibanic, his provincializing act more performative than pedagogic.

In Pleasures of Exile (1960), in a chapter entitled "Caliban Orders History," Caribbean writer George Lamming takes up cudgels on behalf of the "Calibans of the world," i.e. the West Indian islanders, in an attempt to speak back to the "European master race" that had literally left Caliban in a lurch by imprisoning him on his own island, forcing him to deny his mother Sycorax and to imbibe a foreign language and its accompanying cultural paradigm (English/European), and then turning him into a servant when he defied the order thus imposed on him. Lamming identifies with

\footnotetext{
${ }^{23}$ Along similar lines, Rushdie draws a satirical portrayal of the end of the "roseate age of England's precedence" in The New Empire Within Britain (1982): [h]ow fine was the manner of its [the imperial sun's] setting; in what good order the British withdrew. Union Jacks fluttered down their poles all round the world, to be replaced by other flags, in all manner of outlandish colors. The pink conquerors crept home, the boxwallahs and memsahibs and bwanas, leaving behind them parliaments, schools, Grand Trunk Roads and the rules of cricket (55).
} 
Caliban, Prospero's slave on a remote island in Shakespeare's play The Tempest. Their much examined relationship mirrors the opposition between colonizers and colonized. Caliban is not only exiled from his nature but also colonized by language.

For I am a direct descendant of slaves, too near to the actual enterprise to believe that its echoes are over with the reign of emancipation. Moreover, I am a direct descendant of Prospero worshipping in the same temple of endeavor, using his legacy of language - not to curse our meeting - but to push it further, reminding the descendants of both sides that what's done is done, and can only be seen as a soil from which other gifts, or the same gift endowed with different meanings, may grow towards a future which is colonized by our acts in this moment, but which must always remain open (98).

In other words, Lamming's Caliban seems to want not to refuse his European inheritance, but to prove that he was also possessed of reason, albeit non-European reason. ${ }^{24} \mathrm{~A}$ Talebanic refusal of dominant structure, on the other hand would entail, one imagines, an act of virulent denial of the same. As one reads Halwai's testimonial — what he names "The Autobiography of a Half-Baked Indian," - one gets the sense that generationally having never received anything but oppression and revile from dominant power structures in India, Halwai has no stake in revising or critiquing the power that bears down on him. He wants to "kick" them out of contention, just as he promises to hoot out of his personal pantheon all the 30 million or so Hindu gods and goddesses whose "arses" are regularly "kissed" sanctimoniously by the crooked and the corrupt of modern day India (6-7). In fact, in "The White Tiger", Halwai's path through the brief history as a "social entrepreneur" (one who takes the initiative to actualize, against adversity, his own human potential and raise himself mercurially in the world) bears uncanny resemblance to that of the fundamentalist. Having accomplished his one decisive act of "social entrepreneurship" by killing his master, in order to migrate from dark India into the region of light, Halwai is on the run from the law. On his way from Delhi to Bangalore, he sees a police poster with his face on it stapled to an adjacent poster "of two guys from Kashmir - two terrorists wanted for bombing something or the other" (251). The discovery instills not fear but annoyance in him: "You'd almost think," says Halwai, "looking at the posters that I was a terrorist too. How annoying." (251) Halwai seemingly derives satisfaction from this shunting of him by the state into the spectrality of implicit terrorism. However, White Tiger, who prides himself upon being a "thinking man," does not advocate armed insurrection against the powers that be of contemporary India. The implicit terror is an epistemic one. Having unraveled the official India with the pin prick, as it were, of a mock cartography of the nation's rivenness into regions of light and dark, Balram Halwai proceeds to elaborate on the geography of the dark India, exemplified by his home town of Laxmangarh, a remote village in the state of Bihar, a state often described in unflattering terms as India's heart of darkness. ${ }^{25}$

\footnotetext{
${ }^{24}$ George Lamming, Pleasures of Exile, London Pluto, 2005, Pluto Classics.

${ }^{25}$ Labeled "the subcontinent's heart of darkness" by writer Amitav Kumar.
} 
Drawing from Indian mythology, it can be said that Laxmangarh is named after Laxman, the younger brother of Rama, whose heroic exploits comprise the core of the ancient Hindu epic Ramayana. Laxman plays second fiddle to the iconic Rama, and has little to no agency in the text. As Halwai shrewdly observes everything pertaining to the life-world of the Laxmangarh residents and by extension of the vast servant class of India is secondary, indicative of peonage. Thus, Balram himself is named after Krishna's (the king of all Hindu gods and a pivotal agent in the making of the other ancient Hindu epic, The Mahabharata) sidekick, and the resident deity of Laxmangarh is the "monkey god" Hanuman, who is famous for serving Rama unconditionally, even at the risk of losing his life (and tail). The structure of subordination in the Indian cultural landscape, Adiga seems to suggest, runs deep enough to be traced back to the epics, deemed to be the foundational texts of nation-making. But residents of Laxmangarh are not simply second-class citizens; they have been relegated to what anti-colonial theorist, Frantz Fanon describes as the "zone of non-being." The colonizer, writes Frantz Fanon in the context of $20^{\text {th }}$ century European colonialism, severs the "earth's" "wretched," or the colonized, from the (Western) metaphysics of being" to render their subjectivities spectral. To reconstitute their subjectivities, the colonized should use "violence," both against the existing knowledge system that weaponizes reason to justify the colonizer's constructs and against the power structures said knowledge system legitimizes. Colonialism, Fanon argues, is "naked" (or "pure") violence, permeating the colonized's entire matrix of existence, and can only be mitigated by greater violence. ${ }^{26}$ If arguably, the violence of neoliberal capital in $21^{\text {st }}$ century India bears structural resemblance to colonial violence, then should the wretched of the Indian earth reclaim their "being" through violence?

Reflecting on the Maoist insurgency in contemporary rural India, activist Arundhati Roy commends the Maoist guerillas' program of anti-statist violence. Since the 1960s Maoists clashed with the state over conflicting ideologies and territorial claims. In the past few decades, the unprecedented dispossession of land has been central to the country's political economy. During the era of nationalized economy, millions of farmers were shorn of their ancestral land; however, it's only in the years of economic liberalization that the pace of the shearing has accelerated. Moreover, its causes have sifted profoundly, as privatized forms of extraction have exceeded public sector projects as chief enforcers of dispossession. Maoists, in taking the lead to fight land wars on behalf of the nation's agrarian poor, have become the last frontier of armed resistance to neoliberalism's violence against territorial sovereignty of farmlands. While acknowledging the patent anomaly of violence in general in a liberal democracy, Roy insists that Maoists have no choice (but to be violent) because they are pitted against an apriori militarized state that deprives the poor of rights, freedom, and power, in order to enable the rich in their wealth-accumulation

26 In his Wretched of the Earth, and Black Skin, White Masks, Frantz Fanon consistently maintains the uselessness/futility of engaging with the Western colonizer on his own turf, which is the turf of "reason". The history of colonization, Fanon says, is not an emanation of reason, but rather a distortion of the Enlightenment ideals of freedom, equality and humanity. Fanon impales the colonizer on hypocrisy and asks the colonized not to negotiate freedom with the European, but to seize it howsoever violently. 
agenda. However, Roy also contemplates the long-term futility of the Maoist tactic; the originary state violence of India is structural, being rooted in the nation's history and governance legacy. Consequently, it's difficult to uproot the state through armed resistance. According to Roy, a more effective ploy is to "reimagine" the nation itself, to rewrite its history, as it were, by contesting or changing the terms in which postcolonial Indian governmentality is transcribed. ${ }^{27}$ Fanon ascribes the violence of colonial governmentality to the violence of "white" values. Roy attributes the violence of the postcolonial Indian state to the values that are tacitly "white," because they are disseminated in a "language" that perpetuates an Enlightenment hierarchy and disparity by affirming only certain highly racially differentiated conceptions of "truth," "order," "civilization," "progress," and "development," while negating alternative conceptions of the same. Thus, the grander mode of subversion for those pushed to the margins of "civilization," and "progress," would be to ambush the formation of such key conceptions intellectually. Can the poor of Balram Halwai's India write themselves into "being," by contesting and subverting the civilizational norms of growth and progress that, to borrow once more from Frantz Fanon, have become the "universal destiny of all humanity" in the era of globalization?

Some would say that to become a real subject from a spectral one, the poor would need four square meals a day, shelter, and equal access to state institutions. While the logic of such an assertion is irrefutable, it also whittles the condition of poverty into a mere economic fact, similar to what Franz Fanon considers the "fact of blackness" in a dominantly "white" universe. To fix the poor within a conventional construct of resource-deprivation is to submit to the neoliberal framework that sets capital as the norm for both the performing of social identity and for the recognition of others by which the poor are rendered invisible. If the neoliberal "homo economicus" 28 is the ideal subject, and the benchmark against which the poor are measured - literally — as poor, then the poor are set for a conversion into an entrepreneurial subject, a competitive self, thereby, turning themselves, not into a "being", but an additional revenue stream. It could be argued that the poor need to be troped in terms, not only of subjectivities that are overdetermined from without, by the absence of basic necessities, but also as subjects, who, in their multidimensional modes of existences, have the capability of disrupting neoliberalism's grammar, by writing themselves into intelligibility. The goal, for instance, of Balram Halwai is not to get rich, or to be subsumed by the revenue stream of the future, but to illuminate the violence that is folded into the grammar of injustice and inequality prevalent in modern India's politics. In the process of re-writing himself into "being", Halwai becomes more than a merely entrepreneurial economic entity, or what he

\footnotetext{
${ }^{27}$ Walking with the Comrades, brought out by Penguin Random House in 2011, was originally published as a cover story for a 2010 Issue of the Indian News Weekly, Outlook. Roy did an inside report from the jungle camps where Maoist insurgents and tribal villagers were locked in a deadly and drawn-out battle with government forces over mineral-rich land. The villagers, on whose behalf the Maoists have fought a protracted guerilla battle with the state, don't lay claim on the resources, according to Roy, but on the land which is their homeland; the Maoists argue that the villagers who are rendered homeless and refugees in their own country because of state-appropriation of their land, are devoid of "greed."

${ }^{28} \mathrm{~A}$ term coined by Adam Smith.
} 
labels as the "paltu shers" ("domesticated tigers") of neoliberal reason, who reinforce the existing economic order by giving it a semblance of democracy and equal opportunity. ${ }^{29}$

2008, the year The White Tiger won the Man Booker Prize for best fiction in, was a crucial year in the bildungsroman of global neoliberal capital. The financial markets crashed globally, and the crash was largely attributed to worldwide market deregulations. Instead of celebrating the liberating effects of deregulation on India in the global economic sphere, "The White Tiger" exposes the dark side of unregulated growth as mandated by principles of neoliberalism within India. The protagonist, Balram Halwai, in a circumlocuted way, is a beneficiary of globalization, as through entrepreneurship, Balram rises from the proverbial rags to stratospheric riches; globalization, extemporizes Balram, has liberated him from the chains of servitude both to caste and to the bone-breaking poverty of the Indian village. However, while neoliberal capital has freed Halwai in the economic realm, the attainment of capital has also made the servant into an undesirable subject of the state. For Halwai's rise from "non-being" to "being", has not been catalyzed by the instrument of peaceful entrepreneurship but by that of violence: He has had to murder his master, a rich man, to become rich himself; the seed money with which he starts his business is founded on money appropriated from his master. Fulfilling Frantz Fanon's prognosis, the servant/slave has, seized freedom from the master through the medium of violence.

As Halwai confesses in the novel, he kills his master not out of class envy or hunger, as the poor are wont to do in the eyes of the rich, but to consciously shift the paradigm of poverty in India from being perceived as a condition of passive victimhood, to a condition of active complicity by the poor themselves. The poor are agents of their servitude in India, argues Halwai, just as historically India has been an agent of its own servility, serving a succession of masters over time. Conditioned by foreign rule to accept injustice as preordained, the poor in Halwai's rudimentary historiography, are envisioned as caged "roosters", who deflect their violence on the fellow poor, instead of rebelling against those who cage them. Halwai positions himself as a rebel "rooster", determined to fly the "coop", for what the rebellious poor gains is not only access to capital, but also irreducible freedom.

If "The White Tiger" through the praxis of its subaltern-protagonist, calls for a more explicitly violent manifestation of the traditional Marxian class warfare, then one could argue that the poor achieve class consciousness through direct violence. Violence is indeed shown to be an agent of transformation and empowerment in Halwai's trajectory from "non-being" to "being". Following Frantz Fanon, after slaying his master, Balram Halwai is a fundamentally altered being, a "privileged actor", in history's "spotlight", from being a "spectator" crushed into something

\footnotetext{
${ }^{29}$ Arundhati Roy in an interview in which she claimed that $21^{\text {st }}$ century, neoliberal India is not the world's largest democracy in totality that it's made out to be in the global public sphere, but a partially "totalitarian" nation where the poor of India is concerned.
} 
inessential. ${ }^{30}$ The killing of the master is thus a means toward a greater end. In other words, success in the economic dimension of neoliberalism does not make Halwai a self-preserving subject; the murder of his master and the assuming of the master's identity to move up in the world of money as power, is not an act of individuation based on envy and competition that capitalism birthsamongst the poor and rich alike; Halwai's success represents a scaffolded approach to a decolonization of the Indian mind and the Indian consciousness. Halwai, it could be said, wants to rescue the narrative of Indian history from the multiple, hegemonic superstructures of myth to which it has been consigned.

By the novel's end Balram Halwai emerges as a true capitalist, ensconced in the heart of Bengaluru, $21^{\text {st }}$ century India's city upon the economic power hill. If the essence of neoliberal ideology is the achievement of an American-style economic dream promised by capital, then Halwai nails the dream, having risen from the ranks of the impoverished and exploited masses to economic superpowerdom. Yet, Halwai's ascendancy has been actualized not with character or labor but through betrayal and murder. The rise isn't heroic; it's on the side of the mock-heroic, laced with the grotesquery of blood, cruelty and passive-aggressivity. The moral of his story, of which he writes the counter-historical script, is not so much that the poor have to kill for their humanity to be recognized, but rather that the tract of economic and political ascendancy presided over by neoliberal capital, is thick with subterranean violence. Otherwise stated, Halwai's history subserves freedom, not capital, as the node along which the ideal subjectivity of the poor should be fashioned.

It is as though Halwai has come thus far, from being a poor rickshaw puller's son to becoming an entrepreneur as well as a "thinking man," just so he could be free to "speak" his thoughts. For, even the poor have thoughts, about the nation of which they are legitimate citizens. Locutionary freedom, is denied to the masses of "half-baked Indians," the name Halwai gives to the poor like himself, half-literate, undernourished and over-exploited; the name evokes categories of bodies and thoughts that are incomplete and/or irrational, and therefore not "poised" to be integrated into the narrative of Indian modernity. The bodies of the "half-baked" are omnipresent, on the streets of India's industrializing cities, but their life-worlds remain invisible. The half-baked are bodies that are acted upon, but which rarely act back. For instance, Balram remembers his father as being a laconic man whose body is a canvas for history to leave its marks on. "The story of a poor man's life is written on his body, in a sharp pen" (180) says Halwai. The "sharp pen", metaphorically stated, is the "pen" of capital's history of violence; it's also the guns of the annihilatory state apparatus. The history of the poor gets inflicted on the bodies but expunged from the books of India. Thus, the history that gets written into being in India is, in Halwai's estimation, a counterfeit history. "The White Tiger" suggests that the poor can be symbolically empowered through a

\footnotetext{
${ }^{30}$ In his Wretched of the Earth, Frantz Fanon valorizes violent insurrection as a transformative action in the political sphere. In White Tiger, the personal becomes political if we accept Halwai as a paradigmatic servant and his master, Ashok, as representing the violent system that oppresses the poor of India.
} 
legitimization of their lived experiences; Halwai's life world is inscribed into India's historical register as belonging to "dark" India, but the fact of registering is an empowerment in and of itself. It's as though the "subaltern" speaks, albeit in a "half-baked" lingo, in the novel.

The paradox is that a lack of education and English language acquisition, seen as barriers that obstruct the poor of India's "Darkness" from participating in the narrative formation of the nation, are in fact determined by capital, or more specifically, the poor's lack of it. The "Darkness" is marked by lack - of running water, sanitation, healthcare facilities, and opportunities for education and employment. This makes the population vulnerable to exploitation. Being counted as a citizen of this democracy gains almost mythical status. "I've heard that people in the other India get to vote for themselves," Balram's father tells him, "isn't that something?" (100). The divide between the India of the "Darkness" and that of the "Light" is emphasized by the repetition, throughout the novel, of the phrase, "you people" - and its variations, "these people" (267) and "those people" (165). If the pathologies of segregation and the varieties of aggression that the rich show toward the poor, is attributed to capital, then should the poor aim for a subjectivity by rejecting capital? In other words, should the poor resist capital itself or write their life-worlds into being outside the history of it? The poor are invested with a visible subjectivity through the reordering of Indian history by the protagonist of The White Tiger. His act of speaking is a radical disruption of a power that even in the $21^{\text {st }}$ century is colonially inscripted.

In his book Development as Freedom (1999), economist and philosopher Amartya Sen argues that human development ought not to be simply about fulfilling basic economic needs, but about the expanding of citizen's capabilities. Too many of the poverty alleviation programs worldwide entwines development with economic growth, whereas Sen situates development within a fresh conceptual framework of freedom, where freedom means increasing citizen's access and opportunities to the things they have reasons to value. In Aravind Adiga's The White Tiger, the hero, Balram Halwai, could be said to exemplify the goal of "human flourishing" that Amartya Sen posits to be one of the cardinal founding principles of a truly "rich" democracy. At the novel's ending we see Halwai, the entrepreneur, not awash in the pathologies of the rich of India, but in "substantive freedoms" as he walks around the empty streets of Bengaluru at odd hours to "listen to the road." The streets, he says, are the sites of production of his "education", and so he returns to the texts of life, to hear them speak of arterial histories that are epistemically silenced by the sovereign history of state. The streets to Halwai are also rife with revolutionary potential; as a rich man, Halwai does not dream of becoming an instrument for the reproduction of capital, but of inducing a fierce desire for autonomy in the consciousness of the poor. He tells the Chinese premier the following:

"Keep your ears open in Bangalore - in any city or town in India — and you will hear stirrings, rumors, threats of insurrection. Men sit under lampposts at night 
KENTE, 2021

Vol.,2 No.1

and read. Men huddle together and discuss and point fingers to the heavens. One night, will they all join together-will they destroy the Rooster Coop?" (195).

$21^{\text {st }}$ century India troped as a "rooster coop" could be threatened with imminent eruption into freedom, Halwai predicts, if only the poor were to read, not books necessarily, but "the books of revolution" that "sit in the pit" of their own "belly"; the poor need to "crap out" the biopolitical text of insurrection and "read" the texts of their private argot (195). They make for good history. If, as Michel Foucault says, power of capital seizes life itself as the object of its exercise, then a question that arises from reading the fictionalized account of the poor in The White Tiger is what is there in life that resists the power, and in resisting this power creates forms of subjectification and forms of life that escapes its control $?^{31}$ Perhaps for the poor of $21^{\text {st }}$ century India and beyond, the choices are restricted in capitalism, for freedom cannot be staged in capitalist markets which in and of itself is a form of institutionalized unfreedoms. However, Halwai's exertion of his biopolitical freedom resonates: A raucous disruption of the entelechy of capital's history is staged through strategic scorn, first by the subaltern's insertion of himself into the text of the history of the free market in a virulently antinomic way and then by trashing it into a "fucking joke." On his side Halwai has what he calls an epistemology of the "half-baked," within which to re inscribe the history of power from "below"; the effect - of rearticulating a narrative of centrality with a peripheral and incomplete episteme - is a delirious excoriation of the neoliberal epiphany of an expanding and ascendant $21^{\text {st }}$ century India, and the reproduction of the emergent nation as its diametric obverse - as a colonially entropied heart of darkness.

\section{Acknowledgement}

The author would like thank the anonymous reviewers for their comments and suggestions.

\section{Disclosure statement}

No potential conflict of interest was reported by the author(s).

ORCID: Sharmila Mukherjee ID https://orcid.org/0000-0002-8600-5472

\section{Works Cited}

Adiga, Arvind, 2008. The White Tiger: a Novel: New York: Simon and Schuster.

Arendt, Hannah, 1966. The Origins of Totalitarianism. New York: Harcourt, Brace and World. Chakrabarty, Dipesh, 2007. Provincializing Europe: Postcolonial Thought and Historical

\footnotetext{
${ }^{31}$ Foucault, Michel, Michel Senellart, and Graham Burchell. The Birth of Biopolitics: Lectures at the Collège De France, 1978-79. Basingstoke [England: Palgrave Macmillan, 2008. Print.
} 
KENTE, 2021

Vol.,2 No.1

Difference. Princeton University Press.

Chatterjee, Partha, 1992. Nation and its Fragments: Colonial and Postcolonial Histories.

Princeton: Princeton University Press.

Foucault, Michel (trans. Robert Hurley), 1990. The History of Sexuality: An Introduction. New York: Pantheon Books.

Fanon, Frantz, 1957. The Wretched of the Earth. Verso Books.

Frantz Fanon, 1961. Black Skin, White Masks. Verso Books.

Guha, Ranajit, 2003. History at the Limit of World History. New York: Columbia University Press. Lamming, George, 1960. The Pleasures of Exile. University of Michigan Press.

Roy, Arundhati, 2014. Capitalism: A Ghost Story. Haymarket Books.

----2012. Walking With the Comrades. New York: Penguin Books.

Roy, Ananya, 2010. Poverty Capital: Microfinance and the Making of Development. New York:

Routledge.

Sen, Amartya, 1999. Development As Freedom. Oxford University Press.

----2011, The Idea of Justice. Harvard: Harvard University Press.

Spivak, Gayatri Chakrabarty, 1988, “Can the Subaltern Speak?” in Cary Nelson and Lawrence Grossberg Marxism and the Interpretation of Culture. Chicago: University of Illinois Press. 